\title{
MODEL STRATEGI PEMASARAN BERBASIS DIGITAL PADA KOPERASI SIMPAN PINJAM (KONSEP PADA KOPERASI MUGI LESTARI)
}

\author{
Citra Savitri ${ }^{1}$, Mumun Maemunah ${ }^{2}$ \\ Universitas Buana Perjuangan Karawang \\ citra.savitri@ubpkarawang.ac.id ${ }^{\mathbf{1}}$, mumun.maemunah@ubpkarawang.ac.id²
}

\begin{abstract}
ABSTRAK
Perubahan perilaku konsumen pada masa pandemi membawa dampak pada perkembangan bisnis saat ini. Koperasi merupakan salah satu unit usaha yang berdampak pada masa pandemi. Salah satu strategi yang harus dilakukan oleh setiap bisnis adalah meningkatkan atau merubah pola pemasaran dari basis offline menjadi online agar dapat bersaing. Model konsep strategi pemasaran berbasis digital diharapkan mampu memberikan peluang untuk tetap bertahan di dunia perkoperasian. Koperasi Simpan Pinjam Mugi Lestari merupakan salah satu koperasi yang secara langsung berdampak dari masa pandemi. Edukasi tentang peran penting pengembangan pemasaran berbasis digital melalui metode ceramah dan diskusi diberikan sebagai upaya intuk bersaing dan meningkatkan kemampuan dalam mengembangkan bisnis KSP serta upaya untuk melakukan transformasi transformasi dari era konvensional menuju era digital. Hasil yang diperoleh dari kegiatan ini diharapkan dapat memberikan sumbangan bagi KSP Mugi Lestari melalui peningkatan usaha dengan menerapkan strategi pemasaran berbasis digital yang tepat.
\end{abstract}

Kata Kunci : Strategi pemasaran, Digital,Koperasi simpan pinjam.

\section{Abstract}

Keywords :Business Development Strategy,digital,cooperative.

\section{PENDAHULUAN}

Era digital saat ini akan bisa memberikan dampak signifikan terhadap pertumbuhan ekonomi masyarakat. Potensi ini terus perlu dikembangkan dan dimanfaatkan secara optimal oleh semua sektor perekonomian, termasuk sektor Koperasi dan Usaha Mikro, Kecil, dan Menengah atau UMKM. Pemerintah Provinsi Jawa Barat melalui Dinas Koperasi dan Usaha Kecil mendorong upaya pemanfaataan digital atau internet (online) untuk pemasaran produk Koperasi dan UMKM. Perkembangan teknologi tersebut memberikan pengaruh luar biasa pada perilaku konsumen dalam pilihan yang diinginkan. Indonesia sebagai salah satu Negara yang memiliki jumlah penduduk terbanyak di dunia dan penetrasi internet terbesar di Negara Asia(We are Social, 2018) menjadi sebuah peluang usaha bagi para pebisnis koperasi salah satunya. 
Masa pandemi membawa dampak ekonomi yang cukup besar terutama terhadap kelangsungan ekonomi rumah tangga di Indonesia. Keterpurukan ekonomi ini menjadi sebuah cerita buruk bagi semua orang yang terkena dampak virus Covid-19. Organisasi berskala internasional bidang keuangan (International Monetary Fund World I) Bank bahkan memprediksi bahwa ekonomi akan terus mengalami resesi hingga kuartal I tahun 2020 (Liu, Yue, \& Tchounwou, 2020).

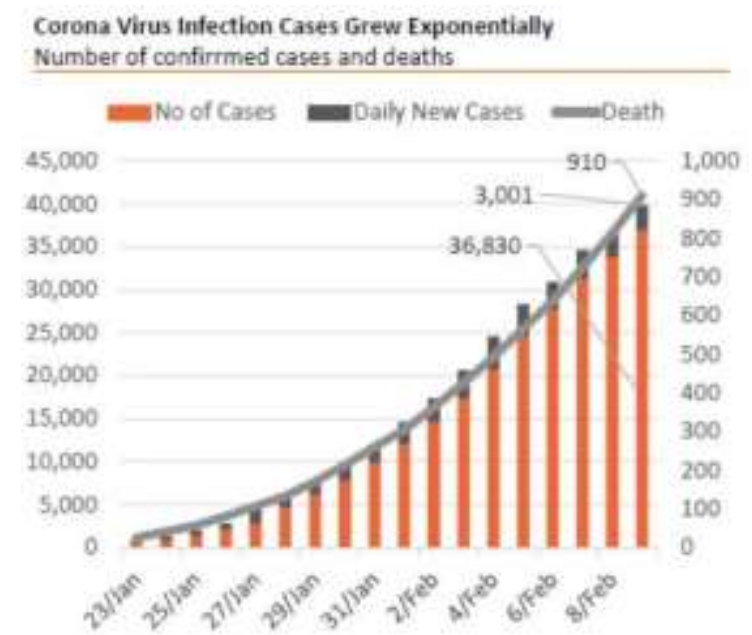

\section{Gambar 1. Corona Virus Infection Cases Grew Exponentially}

Peningkatan jumlah pasien Covid-19 yang terus meningkat memberikan pengaruh yang signifikan terhadap pertumbuhan ekonomi dunia. Penurunan penjualan di berbagai sektor memberikan dampak negatif terhadap keterlambatan ekonomi salah satunya di Indonesia.

Indonesia merupakan salah satu Negara yang terkena dampak dengan kondisi seperti ini tentunya berdampak pada bisnis. Pelaku usaha harus bisa bangkit dan berkembang untuk meninggalkan kondisi buruk ini. Semua bisnis yang biasanya dilakukan di kantor atau di pusat perbelanjaan saat ini sudah banyak beralih ke dunia online. Namun hal ini bisa menjadi sebuah peluang bisnis karena kunci untuk memperluas jaringan pemasaran adalah melalui tekologi e-commerce. "Aktivitas ekonomi digital atau e-commerce berpeluang besar untuk terus berkembang. Baik penjual maupun pembeli sama-sama membutuhkanya, karena e-commerce tidak saja menawarkan kemudahan, tetapi juga efisiensi waktu, tenaga dan biaya," Penggunaan internet di Dunia maupun Indonesia mengalami peningkatan yang sangat signifikan dengan adanya virus corona ini. Namun yang menjadi masalah adalah pelayanan dari setiap perusahaan telekomunikasi mengalami penurunan kinerja sebagai 
Citra Savitri, Mumun Maemunah

Vol. 3 No 1, Februari 2021

ISSN 2657-0203

e-ISSN 2686-0244

bentuk motivasi pekerja untuk menyelesaikan pekerjaan tepat waktu dengan penuh 
kesadaran (Suherman \& Savitri, 2018) akan terhambat. Peran serta koperasi saat ini menjadi penting dalam upaya memenuhi kebutuhan dan keinginan sesuai dengan permintaan konsumen dengan penawaran harga yang ditetapkan dan kemampuan dalam memberikan informasi terkait dengan produk yang dimiliki. Kemampuan dalam transfer information melalui pemasaran digital telah menjadi kebiasaan konsumen untuk mengetahui lebih dalam tentang produk yang dibutuhkan melalui kekuatan e-wom (Savitri, Huriyati, \& Hendrayati, 2021).

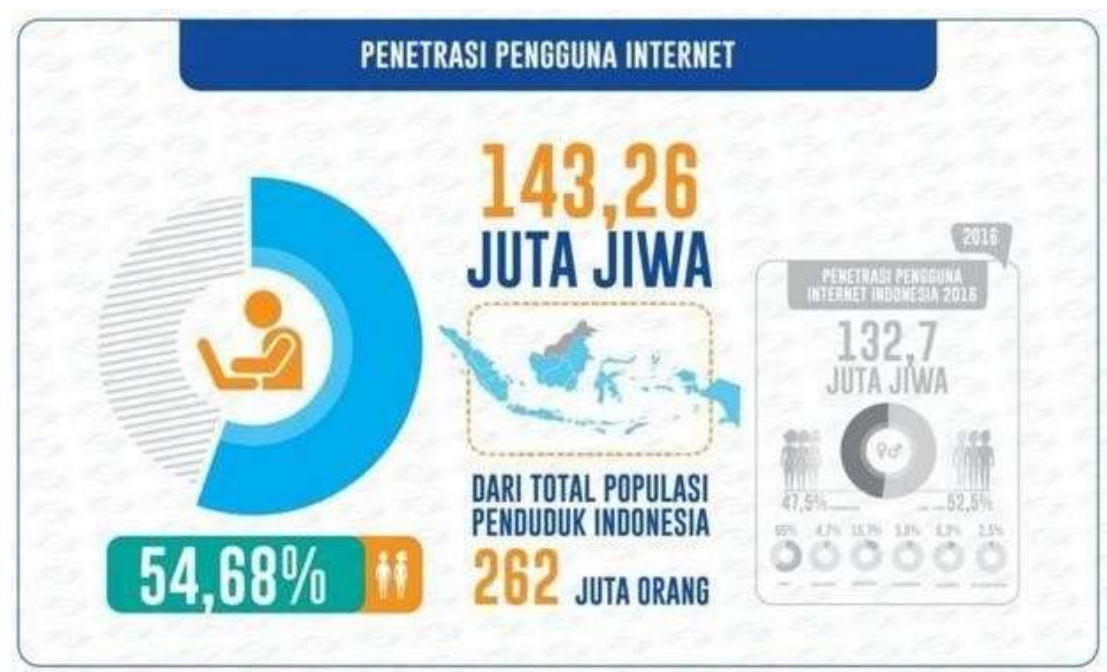

Gambar 2. Penetrasi Pengguna Internet di Indonesia 2018 Sumber : (We are Social, 2018)

\section{METODE}

Metode yang digunakan pada pengabdian ini adalah dengan bentuk metode Pendampingan yang bertemakan Digitalisasi Koperasi di Era Covid-19, dengan judul pengabdian Model Strategi Pemasaran Berbasis Digital Untuk Koperasi Simpan Pinjam Mugi Lestari Karawang. Pengabdian masyarakat ini dilaksanakan di KSP. Mugi Lestari berada di desa Purwadana, kec. Telukjambe Timur Karawang yang terdiri dari pengurus, pengawas dan beberapa anggota dengan menggunakan media online zoom. Alasan tidak dilakukan tatap muka karena kondisi masih belum memungkinkan untuk melakukan tatap muka karena pandemi.

\section{HASIL DAN PEMBAHASAN}

KSP. Mugi Lestari merupakan salah satu koperasi simpan pinjam yang berada di Kabupaten Karawang yang berada di desa purwadana Kecamatan Telukjambe Timur yang lokasinya berada di tempat yang strategis dan mudah dijangkau oleh banyak orang. Potensi lokasi menjadi kekuatan bisnis pada koperasi ini. Namun sejak adanya pandemi membuat perubahan yang cukup signifikan dalam produktivitas bekerja karyawan serta hasil yang 
Citra Savitri, Mumun Maemunah

Vol. 3 No 1, Februari 2021

ISSN 2657-0203

e-ISSN 2686-0244

didapat. Produktifitas dilakukan secara konvensional, mulai dari rapat, koordinasi, pencairan, 
penagihan, dan pengumpulan simpanan anggota. Dari kondisi tersebut KSP. Mugi Lestari harus bisa menyesuiakan diri atas perubahan zaman yang sekarang dikenal dengan istilah revolusi 4.0. perkembangan telekomunikasi yang semakin pesat berkembang dan merubah sistem pelaksanaan industrial kearah teknologi digital memberikan dampak positif dalam hal efisiensi biaya teknis yang harus dikeluarkan serta efektivitas waktu. Tujuan dari sistem digital untuk mempermudah transaksi dan memberikan pengetahun, pelatihan dan pendampingan dalam transforamasi konvensional menuju dunia digital.

\section{Persepsi Responden pada Program Pengabdian Kepada Masyarakat}

Proses pendampingan ini dilakukan sebagai upaya dalam rangka meningkatkan pendapatan KSP Mugi Lestari melalui beberapa tahap, antara lain :

1. Analisis situasi dan kondisi lapangan

2. Perencanaan peluang hasil dari analisis situasi

3. Pelaksanaan pelatihan berbasis digital

4. Monitoring pelaksanaan strategi pemasaran berbasis digital

5. Evaluasi model strategi pemasaran berbasis digital

Sebelum kegiatan dilaksanakan , peserta diminta untuk memberikan informasi terkait tentang kondisi dan situasi yang ada di KSP Mugi lestari saat ini sebagai bahan dalam merancang model yang dapat digunakan.

\section{Proses Pendampingan}

Terdapat 3 (tiga) langkah kegiatan pelatihan dan pendampingan yaitu: analisis situasi, perencanaan, pelaksanaan serta monitoring dan evaluasi.

Kegiatan yang telah dilaksanakan adalah analisis situasi melalui penyampaian materi melalui media online zoom sebagai tempat interaksi antara tim pengabdian dengan mitra. Dari kegiatan pengabdian masyarakat ini disarankan KSP. Mugi Lestari agar lebih memahami pemanfaatan internet secara luas sehingga dapat diimplementasikan dalam pengambilan keputusan di berbagai kegiatan koperasi. Sehingga setelah memahami manfaat internet dan dapat melakukan implementasinya di KSP. Mugi Lestari, untuk kegiatan selanjutnya dapat dilakukan pengabdian fokus kepada konsultasi apakah yang diimplementasikan sudah sesuai atau belum. Target dan luasarn kegiatan pengabdian masyarakat ini secara rinci dapat tergambar pada tabel sebagai berikut: 
Citra Savitri, Mumun Maemunah

Vol. 3 No 1, Februari 2021

ISSN 2657-0203

e-ISSN 2686-0244

\begin{tabular}{|c|c|c|c|}
\hline No & Jenis Luaran & Partisipasi Mitra & Target \\
\hline 1. & $\begin{array}{l}\text { Pemahaman akan } \\
\text { kebutuhan } \\
\text { penggunaan digital } \\
\text { marketing bisnis pada } \\
\text { usaha mitra }\end{array}$ & $\begin{array}{l}\text { Mitra merespon } \\
\text { positif atas } \\
\text { penyelenggaraan } \\
\text { kegiatan }\end{array}$ & $\begin{array}{l}\text { Adanya antusias mitra } \\
\text { untuk memahami } \\
\text { lebih dalam lagi } \\
\text { tentang pemahaman } \\
\text { pentingnya mengusai } \\
\text { digital bisnis. }\end{array}$ \\
\hline 2. & $\begin{array}{l}\text { Monitoring dan } \\
\text { evaluasi }\end{array}$ & $\begin{array}{l}\text { Mitra merespon } \\
\text { positif atas } \\
\text { penyelenggaraan } \\
\text { kegiatan }\end{array}$ & $\begin{array}{l}\text { Mitra diharapkan } \\
\text { merencakan kegiatan } \\
\text { pelatihan berbasis } \\
\text { digital bisnis } \\
\text { dikemudian hari }\end{array}$ \\
\hline
\end{tabular}

\section{Hasil Pendampinga Tahap 1}

Dari hasil diskusi, wawancara dan penyampaian materi yang telah dilaksanakan ada beberapa hal yang didapat antara lain :

1. Karyawan memiliki pengetahuan dan kemampuan dalam menganalisis kebutuhan dan keinginan anggota koperasi

2. Pemanfaatan teknologi dan informasi sebagai media penghubung secara langsung kepada calon anggota belum dimanfaatkan secara maksimal

3. Strategi pemasaran yang dilakukan masih menggunakan metode offline

4. Belum memiliki sistem dan aplikasi digital

\section{KESIMPULAN DAN SARAN}

Kesimpulan dari kegiatan pengabdian pada KSP. Mugi Lestari antara lain :

1. Pemahaman lebih dalam lagi tentang pemahaman pentingnya mengusai digital bisnis.

2. Perencanaan kegiatan pelatihan berbasis digital bisnis

3. Strategi pemasaran berbasis digital bagi koperasi simpan pinjam

4. Kemampuan bersaing dalam bidang teknologi sebagai wujud 
Saran pada kegiatan pengabdian ini agar dapat dikembangkan dalam pelatihan berbasis teknologi pada strategi pemasaran koperasi simpan pinjam.

\section{DAFTAR PUSTAKA}

Afri Erisman, Ph. D : Manajemen Strategis. Penerbit Deepublish.

J. David Hunger \& Thomas L Wheelen, Manajemen Strategies

Hermawan, Agus. Komunikasi Pemasaran.2012. Penerbit Erlangga: Jakarta Jacobsen, Bjorn P (2009), Investor Creatifity. Journal of Place Management and Development Vol 2 No 1.

Liu, W., Yue, X. G., \& Tchounwou, P. B. (2020). Response to the covid-19 epidemic: The chinese experience and implications for other countries. International Journal of Environmental Research and Public Health, 17(7), 1-6. https://doi.org/10.3390/IJERPH17072304

Savitri, C., Huriyati, R., \& Hendrayati, H. (2021). The power of EWOM for online business. Advances in Business, Management and Enrepreneurship, 4(1), 329-331.

Suherman, E., \& Savitri, C. (2018). Analisis Peran Self Efficacy Dan Motivasi Kerja Terhadap Kinerja Marketing Dealer Wijaya Toyota Subang. Buana Ilmu, 3(1), 70-89. https://doi.org/10.36805/bi.v3i1.457

We are Social. (2018). Penetrasi Pengguna Internet. Retrieved from We Are Social. $\%$ 22Empowering business in Southeast Asia-aseanup.com.

Rangkuti, Freddy. Strategi promosi yang kreatif dan analis kasus IMC.2009. PT Gramedia, Pustaka Utama: Jakarta

Savitri, C., Huriyati, R., \& Hendrayati, H. (2021). The power of EWOM for online business. Advances in Business, Management and Enrepreneurship, 4(1), 329-331.

Suherman, E., \& Savitri, C. (2018). Analisis Peran Self Efficacy Dan Motivasi Kerja Terhadap Kinerja Marketing Dealer Wijaya Toyota Subang. Buana Ilmu, 3(1), 70-89. https://doi.org/10.36805/bi.v3i1.457

Sulaksana, 2007. Integrated Marketing Communication, Jakarta: Quantum. Saputra, Wahidin, 2011, Public Relations Teori dan Praktik Public Relations di Era Cyber, Depok: Gramata Publishing.

Tjiptono, Fandy, 2009. Strategi Pemasaran: Manajemen Jasa, Yogyakarta: Andi Publisher.

We are Social. (2018). Penetrasi Pengguna Internet. Retrieved from We Are Social. \%22Empowering business in Southeast Asia-aseanup.com.

Wiley, Yoeti. A. Oka, 1996. Manajemen Pemasaran, Jakarta : Perca. Yananda, M Rahmat.Branding Tempat Membangun Kota, Kabupaten, dan Provinsi Berbasis Identitas.2011. PT Makna Informasi Indonesia: Jakarta 